\title{
ON IMPROVING FINANCIAL LITERACY
}

\author{
Levente Kovács - Ágnes Sütö
}

Improving financial literacy and skills is in the self interest of both the government and the financial sector. If banking customers select and use financial products and services consciously and ethically, they will promote and strengthen confidence in and respect for the government and the financial sector while payments discipline and tax compliance will improve. Thanks to smart customers, the effects of a potential financial crisis can be mitigated; since panic responses, which can significantly multiply the harmful effects of a crisis, are less expressed among them. Overall, being knowledgeable in finances supports the reliable operation and growth of the economy. The objectives of PÉNZ7 matching the Pan-European Money Week programme are to improve financial literacy and enterprising skills from primary and secondary schools to universities. The Hungarian Banking Association acknowledge committed people and institutions of outstanding performance by giving them the award Ambassador of Financial Culture. In this paper the ideas of earlier holders of the award describe the improvement of financial literacy and the impact of the PÉNZ7 programme.

This paper has been prepared for the 2020 theme week of finance and enterprise, PÉNZ7 (2-6 March 2020).

JEL codes: $\mathrm{G}_{53}$, A20

Keywords: financial literacy, financial education, PÉNZ7

1 Levente Kovács, Secretary General, Hungarian Banking Association. E-mail: kovacs.levente@ bankszovetseg.hu.

Ágnes Sütő, Deputy Secretary General of Communication, Hungarian Banking Association. Email: suto.agnes@bankszovetseg.hu. 


\section{IMPROVING FINANCIAL LITERACY IS IN THE SELF-INTEREST OF THE GOVERNMENT AND THE BANKS}

At the time of the management of the 2008 financial crisis it became clear that the lack of financial skills and the low level of financial literacy played a major part in the aggravation of the crisis and its extension in time. During the economic crisis, trust in the financial sector was undermined, its general appreciation reached its lowest, financial discipline eroded, etc. Governments turned to fire-fighting measures, which meant fast crisis management solutions irrespective of their outcome, budget cuts, and strict banking and regulatory measures in finances, as well as bank bailouts in some countries. The measures were typically inadequate to restore confidence in the financial sector. Dissatisfaction, passing the buck and the lack of payment discipline and incompliance with the rules spread, unfortunately, to other areas and sectors too (Kovács-Terták, 2019, Chapter 1).

In general, the imbalance of fiscal and monetary policies, unsuccessful government solutions of crisis management, rumours striving for media attention, social dissatisfaction and the low level of consumers' financial literacy all contributed to the aggravation of the crisis and its extension in time.

Global and national financial studies soon provided proof for the low level of financial skills, increasing which must be one of the key tools to prevent similar situations in the future. Thus, improving financial literacy is in the (self)interest of both government administration, the institutions and the whole financial sector.

To promote financial convergence in Hungary, the Ministry of Finance designed the 'Strategy of improving financial literacy' with the following main objectives for the period 2017-2023:

1) Set out a framework for real financial education within public education, its implementation and strengthening.

2) Lay the foundations of conscious financial behaviour and strengthening the financial stress resistance of households.

3) Create an attitude promoting careful financial decisions, designing institutions/infrastructure supporting consumers' conscious financial behaviour and dissemination of knowledge in society.

4) Strengthen the population's attitude to self-support.

5) Increase access to financial products and basic financial services as well as financial inclusion.

6) Promote the use of modern cash saving payment methods.

7) Support prudent borrowing (Financial Awareness, 2017). 
Coordinated with the above set of objectives, the banking sector joined, among others, the programmes Global Money Week and - in the EU - the European Money week announced by the European Banking Federation (EBF). PÉNZ7 is the Hungarian programme of the above with its group of organisers continuously expanding since 2014 in an exemplary coordination of government, market and non-profit players. In 2020 the organisers include the following: The Ministry of Human Resources, the Ministry of Finance, the Ministry for Innovation and Technology, the Hungarian Banking Association, the Money Compass Foundation, and the Junior Achievement Hungary Foundation. Topical financial and enterprising knowledge is disseminated under PÉNZ7 to approximately 250 thousand students every year through the classes of school theme weeks with the help of volunteers recruited from banks and enterprises and specifically trained teachers. It is a real success that the improvement of financial literacy and enterprising skills through theme weeks has become part of the official school curriculum in Hungary within a short time. The success of the initiative is proved by the fact that - following the example of PÉNZ7 - a Sustainability and Digital Theme Week has also been established dealing with similar topical and essential issues.

\section{AMBASSADORS OF FINANCIAL LITERACY}

Any wide-ranging social programme can only become successful long term if it is supported by committed voluntary institutions and enthusiastic 'standard-bearers' side-by-side with the government initiative. The Hungarian Banking Association as the initiator of $\mathrm{PÉNZ}_{7}$ in Hungary has been striving ever since its start to acknowledge outstanding performance. That is why the award 'Ambassadors of Financial Literacy' has been established. Next, some ideas of earlier holders of the award, both individuals and institutions, are shared as they responded to the same question.

\section{Why is improving financial literacy important?}

Éva Hegedüs (sponsor of the programme $\mathrm{PENZ}_{7}$ on behalf of the Presidency of the Banking Association): Improving financial literacy and spreading financial skills can assist people in, among others, their preparations to make prudent decisions when they select the offers available on a competitive banking market and not to decide following earlier routines. I believe that you can achieve a better life if you know more. The improvement of financial literacy and skills influences the development of the whole country, i.e., it will not only improve the financial situation and life of banking customers but the position of the Hungarian economy as well. 


\section{Personal awards}

László Balogh (Deputy State Secretary of the Ministry of Finance): Financial skills, knowledge and behaviour are of key importance for everybody in the $21^{\text {st }}$ century since you must make financial decisions all the time in the current economic environment. The skill of making smart financial decision is at least as important for a person or for whole families as the improvement of digital skills. As decisions made by families are getting smarter they are added at the level of the national economy: they stabilise the position of families but also of the national economy. Improving culture is a lengthy process with its focus on shaping people's mentality and way of thinking... The objective of the government strategy aiming to improve financial literacy is to achieve that financial skills become integral parts of school curricula, similarly to e.g., digital skills.

\section{Andrea Bánki (Ministry of Human Capacities - EMMI, PÉNZ7 POB member):} It is important for a conscious lifestyle that beginning from childhood you receive and incorporate in your thinking pieces of information, including financial information, that are built upon each other and help the process of socialisation through which you become mature adults and can plan your life skilfully. People must learn how to balance their life goals with their material resources and possibilities. Such knowledge also has an important, positive social impact.

\section{Sándor Brassói (Educational Authority, Deputy Chairman for Public Educa-} tion): The range of different services available on the Internet is expanding fast these days. The dynamics in the field of finance is sometimes difficult for many to follow, particularly for the older generations. Mobile phone applications assist faster shopping and other finance related activities. All that necessitates to provide education at schools helping youngsters to prepare for the challenges of online finances and business issues with the help of professionally compiled programmes.

Eszter Hergár (Money Compass Foundation, Chairperson): All players of the financial sector need customers who can find their way, understand financial products and make responsible decisions about them. The stability of the national economy also requires that households, companies and government agencies understand and apply financial skills in their day to day activities. Pursuant to its legislative authorisation, the National Bank of Hungary is an active player and committed promoter of spreading financial knowledge. 
Csaba Lentner (University of Public Services - NKE, university professor): Financial literacy is of key importance for the competitive edge of the Hungarian national economy. A stable economy needs stable banks and - mainly - financially stable households. So, educating people to achieve financial awareness and prudent economic management from a young age is a task for the whole society.

Zoltán Maruzsa (EMMI, State Secretary): When I was a boy, my father used to say, "it is more difficult to keep money than to earn it", and also that "money should never burn your pockets" so I have learnt this lesson. Nevertheless, I met many people in my career who were not given the same advice. That is why we must act at school to educate youngsters for financial awareness even if they do not hear about it at home. The goal of financial education is to teach students to recognise their own responsibility in terms of prudent management of assets in a world of money and consumption. If young people learn financial awareness, their financial skills and knowledge will attain a higher level, so they can make better financial decisions, their entrepreneurial competence is improved, which contributes to the competitiveness of Hungary.

Zsuzsanna Merényi (Money Compass Foundation, Director of Studies): We have been living in a market economy for 30 years, there are no situations in life lacking financial reference, there are no adult jobs or family decisions that would not require responsible management of your resources. Financial literacy including an attitude to sustainability is the foundation of the operation of our world.

Anikó Sisa Molnár (Mastercard, Executive Director): As a front runner company in innovation, Mastercard consider it important to make available the technology we developed to all strata of the Hungarian society to facilitate their everyday finance matters making them simpler and safer. To achieve that we need programmes helping consumers to learn about those solutions shaping their financial mindset and habits in that way. As the mother of a smart 9-year old son, I can see very well that starting financial education as early as at primary school is necessary today.

Mrs. Szolnoki, Judit Pap (National Bank of Hungary, Head of Department): The 2007-2009 financial crisis clearly called attention to the fact that the low standard of financial literacy often resulted in financial decisions lacking the proper care, which might have had severe consequences for the material position and financial security of families. In addition to individual effects, the social and macro-economic consequences are also important: just think of the sustainability of the pension scheme or people's attitude to self-support in that regard. 


\section{Institutional awards}

ERSTE Bank: The First Austrian Savings Bank was established 200 years ago in a small church in Vienna. The savings bank mainly offered average people financial services encouraging them to think of their future and to manage their finances consciously with the help of their savings. The mission of the Erste Group has not changed over the past 200 years: our primary goal is to promote our customers' well-being and financial health by improving their financial literacy - an important, inseparable part of it.

K\&H Bank: Youngsters are interested in the world of money already at an early age. We must explain to them financial issues in a way matching their age. When they have already obtained basic mathematical skills, we can talk to them about prices and can make them perceive the value of money. Then, we can deal with more complex financial concepts; that is how we can educate the young generation into financially conscious adults.

Fundamenta Home Savings Fund: Improving financial literacy is a key part of increasing the population's willingness for self-support. This is the mission of Fundamenta, which plays a major part via its nation-wide distribution network. Education is really important in the market of home savings and home loans, since our customers often plan for 5-15 or even 20 years when they make decisions on buying, enlarging or refurbishing their homes and on the financial implications of their plans.

MKB Bank: It is important not only for the banking sector but also for the economy and for social welfare in a wider sense to achieve that our customers including the future generation, i.e., our future customers, possess the necessary knowledge to be able to make conscious and prudent financial decisions. A current and good example: educating customers and driving financial transactions towards electronic channels is of key importance if you want to reduce the stock of cash used in Hungary, which is higher now than ever before. In its competition for satisfied customers, MKB Bank has always been paying special attention to the quality of its services and has been striving to offer its customers safe, fast and accessible services whether personally or online.

Financial Consumer Protection Centre MNB/Csaba Kandrács: The MNB is aware that financial literacy is a level of financial skills and knowledge that will assist consumers to make conscious and prudent financial decisions, to identify the relevant information and - the most important - to avoid risks. Although several steps have been taken in this direction over the past few years, international 
surveys suggest that further measures are required. The National Bank is using all its means of communication to achieve that.

OTP Group/András Becsei: Only a small part of the generations growing up over the past decades received financial training, which is indispensable in everyday life. It is our number one task to promote the expansion of knowledge using all means available. Highly effective online platforms naturally lend themselves for the purpose today. On the other hand, inspirational financial education through experiments in a modern environment and using up-to-date tools are key if you want to direct increased attention to the topic and raise awareness. The 'Fáy András' Foundation of OTP Bank strives to attain this goal by increasing young people's demand for a mindful management of their everyday finances via its cross-border activities.

'Fáy András' Foundation of OTP: Conscious financial management is one of the pillars of a conscious future. Achieving financial literacy lays the foundations for proper money management, making prudent financial decisions and creates a kind of financial security, all of which contribute to the well-being of the individual, the family and the closer or wider community, to the feeling of stability. The 'Fáy András' Foundation of OTP has been professionally operating to attain those goals for almost three decades promoting in that way the prosperity of society in future.

\section{THE PART PLAYED BY PÉNZ7, ITS SOCIAL IMPACT AND INSTITUTIONAL BEST PRACTICES}

PÉNZ7 was launched in Hungary in 2014. It has been developing ever since and its message has been spread to an ever-widening group of people. In recent years, about 200,000 registered students took part in the programmes of the theme weeks every year.

Although it has been a short span of time, its impacts can already be felt and the 'best practices' designed by leading institutes have become visible.

The winners of the award were asked two questions:

1) 'How do you see the part played by PÉNZ7 and its impact on the field?'

2) 'What do you think the best practices to improve financial literacy are?'

Here are the answers: 


\section{The social impact of $\mathrm{PÉNZ}_{7}$}

"The series of events PÉNZ7 is a great help for students to learn more about financial issues and to be given answers to topical questions by the volunteers of the financial sector taking part in the programme." (Éva Hegedüs)

"PÉNZ7 allows students to supplement their academic knowledge about the world of money and business with practical skills.” (Sándor Brassói)

"School children are the most receptive for novelties because their thinking about money and financial literacy is formed in those years." (Anikó Sisa Molnár)

"Colourful classes based on real experience have a positive impact... children often take the experience home, so their parents' attention can also be directed to the importance and usefulness of the topic.” (Mrs. Szolnoki, Judit Pap)

"We do hope that conscious financial planning becomes an everyday practice in the life of more and more families, so that they can shape their life more reliably and make it better not only from an economic but also from an emotional perspective." (Csaba Lentner)

"The excellence of the programme is its impact on everyday life by spreading skills that are useful in your life." (Andrea Bánki)

"Although financial skills are part of the basic knowledge to be passed on by schools, they are sometimes not paid proper attention in the curriculum... The safety of consumers and financial clients is also a question of financial stability... It contributes to making the proper information available to those involved to make better financial decisions." (Csaba Kandrács)

"The number of finance managers and professionals who act as volunteers in delivering the classes is increasing. They take such kind of social responsibility as granted, expressing their commitment and responsibility for the financial education of the young generation. PÉNZ7, financial education has become a real public issue.” (Eszter Hergár)

"PÉNZ7 fits into the government strategy, it is one of the most successful programmes. $\mathrm{PÉNZ}_{7}$ has been helping people by providing up-to-date financial knowledge and practical advice so that they become smart, well-informed, conscious and intelligent users of financial products." (László Balogh)

"PÉNZ7 has become a tradition providing excellent opportunities to raise awareness and discuss topical issues, which is repeated every year as a result of collaboration never seen earlier. We would need many more such initiatives." (András Becsei) 


\section{Best practices at the winner institutions}

The 'Fáy András' Foundation (OTP Bank) has set up a unique educational scheme applying special tools and solutions continuously updated that is able to reach masses of people; it is built on its own educational methodology developed inhouse based on experience to provide efficient knowledge. It is done in an inspiring educational environment considering different age groups' level of knowledge, their needs and opportunities and adjusts its teaching materials accordingly so that they also meet the criteria of international educational trends.

The employees of Erste Bank support several non-governmental organisations and initiatives. As part of their efforts, they offer voluntary help in financial education to assist the operation of socially useful enterprises and the work of the heads of the foundations. In addition, as part of the SEEDS Programme of Erste Bank, socially useful enterprises are offered comprehensive training, while under the Financial Literacy Programme young people of financial skills below average - mainly Roma, young people with mental disabilities, youth living in extreme poverty or drug addicts - are given financial education.

In the course of its communications activity, Fundamenta pays special attention to financial education also on its social media platforms. Its Personal Bankers pay great attention to assessing their clients' housing related plans at personal meetings and to finding the best scheme of home savings that can be sustained long term.

In the K\&H Ready, Steady, Money! financial quiz primary and secondary school children have already been acquiring financial skills for 10 years. In addition, the participants can not only come across financial issues in the quiz, but they can visit a bank branch nearby under our bank branch mentor programme, where they can see how our colleagues work.

MKB Bank as a socially responsible and committed bank believes that banks must invest into the improvement of financial literacy in this country. MKB was the first in Hungary to pay outstanding attention to supporting financial start-ups engaged in the development of digital technologies. The improvement of financial literacy is also supported by the function Personal Finances of the internet platform of MKB Bank 'NetBANKár'. With its help, customers get a comprehensive picture of their finances so they will be able to monitor and analyse their revenues and spendings more efficiently. Under a strategic agreement, the MKB Finance Group cooperate with several institutes of higher education and national federations. The Group provides donations, supports trade programmes, financial training programmes and quizzes (e.g., LETIMOB), as part of their efficient and value-creating work for a balanced economic development of the country. 


\section{SUMMARY}

Government and market players joined hands in Hungary to make the programme $\mathrm{PÉNZ}_{7}$ successful. It has grown into a public educational programme reaching a high number of schoolchildren over the past few years. It is organically supplemented by attractive interesting and spectacular programmes offered by different market players.

Side by side with shaping public awareness, the teaching materials and topics of PÉNZ7 systematically designed contribute to improving financial literacy and the enterprising culture of the children's parents and - in the end - of the whole society.

\section{REFERENCES}

Pénzügyi tudatosság fejlesztésének stratégiája [Strategy of improving financialliteracy] (2017), https:// www.kormany.hu/download/5/39/2100o/P\%C3\%A9nz\%C3\%BCgyi\%2otudatoss\%C3\%A1g\%20 fejleszt\%C3\%A9s\%C3\%A9nek\%2ostrat\%C3\%A9gi\%C3\%A1ja.pdf.

Levente KovÁcs - Elemér Terták (2019): Financial Literacy: Theory and Evidence. Bratislava, SK: Verlag Dashöfer, 150 p. ISBN: 9788081781209.

The answers given to our survey by the individual and institutional award holders of "The Ambassadors of Financial Literacy" (2019). 